\title{
PENGARUH KUALITAS PELAYANAN DAN KUALITAS PRODUK TERHADAP LOYALITAS PELANGGAN AIR MINUM ISI ULANG BANYU BIRU
}

\author{
*(Luluk Nur Azizah \\ Prodi Manajemen, Fakultas Ekonomi, Universitas Islam Lamongan \\ $\mathrm{Jl}$. Veteran No.53A Lamongan \\ Telp. ( 0322 ) 324706, Faks. (0322) 324706 \\ Email :jpim.unisla@gmail.com
}

\begin{abstract}
ABSTRAK
Penelitian ini bertujuan untuk mengetahui pengaruh kualitas pelayanan dan kualitas produk terhadap loyalitas pelanggan air minum isi ulang banyu biru. responden yang terlibat dalam penelitian ini sebanyak 100 pembeli. metode yang digunakan adalah sampel populasi. pengumpulan data dilakukan dengan menyebar angket. metode analisis data dilakukan dengan regresi linier berganda menggunakan software spss. hasil uji regresi menunjukkan bahwa variabel kualitas layanan dan kualitas produk berpengaruh positif dan signifikan terhadap loyalitas pelanggan. sedangkan variabel yang dominan pengaruhnya terhadap loyalitas pelanggan adalah kualitas produk. berdasarkan hasil penelitian tersebut dapat disimpulkan bahwa kualits pelayanan, kualitas produk berpengaruh positif terhadap loyalitas pelanggan
\end{abstract}

Kata kunci : Kualitas Pelayanan(X1), Kualitas Produk(X2), Loyalitas Pelanggan (Y)

\section{PENDAHULUAN}

Perusahaan pada umumnya menginginkan apa yang diproduksi dapat dipasarkan dengan lancar dan menguntungkan. Berawal dari hal tersebut perusahaan akan menginginkan, agar pelanggan yang sudah diciptakan dapat dipertahankan selamanya. Namun hal tersebut bukanlah merupakan hal yang mudah, mengingat beberapa perubahan dapat terjadi setiap saat, baik perubahan pada diri pelanggan, seperti selera maupun beberapa aspek psikologis sosial dan kultur pelanggan.

Dalam jangka panjang loyalitas pelanggan menjadi tujuan bagi perencanaan pasar strategis, selain itu juga dijadikan dasar pengembangan keunggulan yang berkelanjutan, yaitu berbagai keunggulan yang dapat direalisasikan melalui upaya-upaya pemasaran. Dalam lingkungan persaingan global yang semakin ketat dengan masuknya beberapa produk yang inovatif ke pemasaran di satu sisi dan kondisi pasar yang semakin jenuh untuk beberapa produk tertentu di sisi lain, menyebabkan tugas untuk mengelola loyalitas pelanggan menjadi tantangan manajerial yang tidak ringan, kepergian pelanggan merupakan salah satu kadar ukuran yang paling nyata didalam bisnis. Kepergian pelanggan merupakan pertanda yang paling mungkin, bahwa pelanggan melihat 
suatu aliran nilai yang merosot dari suatu perusahaan. Suatu tingkat kepergian yang meningkat, merupakan suatu pertanda akan adanya pengurangan cash flow dari pelanggan kepada perusahaan (meskipun perusahaan mampu mengganti pelanggan yang hilang), karena untuk mendapatkan pelanggan baru membutuhkan biaya dan pelanggan lama cenderung memberikan cash flow serta keuntungan yang lebih besar dibandingkan dengan pelanggan yang baru.

Loyalitas adalah tujuan utama para pemasar atas produk, merk ataupelayanannya, kekuatan dari pelanggan sebagai salah satu kunci sukses dalambisnis (Tjiptono: 1997). Pelanggan yang loyal pada suatu produk tertentu akan memberikan prioritaspertama dalam berbelanja pada produk tersebut. Hal ini dapat berlangsung dalamjangka panjang dan berakhir pada saat terjadi ketidak cocokan yang akan memutusikatan kuat antara pelanggan dengan produk.Loyalitas pelanggan memiliki hubungan kausal dengan kualitas jasa.Terjadinya loyalitas merk pada konsumen disebabkan adanya pengaruh kepuasanatau ketidakpuasan pelanggan terhadap merk tersebut yang terakumulasi secaraterus-menerus disamping adanya persepsi tentang kualitas.

Loyalitas pelangganjuga dipengaruhi oleh kualitas produk. Kualitas produk dapat digunakan untukmengembangkan loyalitas pelanggan (Tjiptono:1997). Beberapa hasil penelitian menunjukkanbahwa konsumen akan menjadi loyal pada beberapa merk berkualitas tinggi. Dalamhal kualitas, kualitas produk juga mengandung makna adanya kualitas pelanggan.Pada dimensi kualitas produk atau jasa di dalamnya termasuk berbagai hal yangberkaitan dengan kualitas pelayanan, yaitu tangibles, reliability, responsiveness, assurance dan emphaty.

Kualitas pelayanan merupakan suatu bentuk penilaian konsumen terhadaptingkat pelayanan yang dipersepsikan (perceived service) dengan tingkat pelayanan yang diharapkan (expected service). Kualitas pelayanan akan dihasilkan oleh operasi yang dilakukan perusahaan, dan keberhasilan proses operasi perusahaan ditentukan oleh banyak faktor, antara lain faktor karyawan, sistem, teknologi dan keterlibatan nasabah (Tjiptono:1997)..

Pada umumnya, semakin lama seorang pelanggan bertahan pada suatu perusahaan, semakin berharga pelanggan tersebut. Para pelanggan lama melakukan lebih banyak pembelian dan biasanya membawa masuk pelanggan baru. Lebih dari itu, pelanggan lama tidak membutuhkan biaya awal (biaya pemasaran untuk mencari pelanggan baru). Pelanggan lama yang baik, sangat berharga pada sebagian besar industri, karena pelanggan ini dapat mengurangi kepergian pelanggan sebesar $10 \%$ sampai dengan $15 \%$ per tahun (Fornell:1992) . Berdasarkan pengalaman masa lampau yang diukur dengan variabel, yaitu tingkat kepuasan pelanggan dan rekomendasi dari mulut 
ke mulut memiliki keterkaitan dengan loyalitas pelanggan. Keluasan asosiasi antara kedua variabel tersebut adalah kuat dan stabil. Oleh karena itu implikasinya bahwa pihak manajemen seharusnya mempertimbangkan dan mendidik pemasar mereka dalam pelayanan terhadap konsumen sebagai langkah untuk meningkatkan citra perusahaan

Air minum merupakan produk konsumsi yang sangat dibutuhkan oleh manusia dimanapun dan kapanpun, dimana air merupakan sumber kehidupan manusia yang utama, sekarang maraknya bermacam-macam merek air minum dari mulai air minum pabrikan sampai air minum isi ulang. Salah satunya air minum isi ulang yang lagi digemari masyarakat adalah air isi ulang BANYU BIRU, dimana air isi ulang BANYU BIRU tersebut mempunyai kelebihan dari pada air isi ulang yang lainnya, air isi ulang BANYU BIRU menawarkan pelayanan yang mengutamakan pelangan termudahkan dalam setiap kebutuhan air minumnya dengan pelayanan yang peneliti rasa sangat bagus, keunngulan yang lainnya adalah diproduknya dimana air isi ulang BANYU BIRU ini dalam DAM BANYU BIRU menggunakan 100 persen teknologi (www.bayubiru:2013) ozon untuk proses produksi air minum yang dihasilkan teknologi ozon merupakan standart industry yang digunakan oleh perusahaan Air Minum Dalam Kemasan (AMDK) sehingga air yang dikonsumsi mempunyai syarat-syarat yang semestinya diperlukan, seperti kaya akan oksigen yang terlihat nyata dengan adanya butir-butir oksigen dalam botol galon. Tingkat kesegaran air minum BANYU BIRU pasti lebih terjamin karena penjualan segera setelah proses produksi selesai.

\section{LANDASAN TEORI \\ Kualitas Pelayanan}

Kualitas layanan merupakan keseluruhan berbagai ciri dan karakteristik dari suatu produk atau jasa dalam hal kemampuan untuk memenuhi berbagai kebutuhan yang telah ditentukan atau yang bersifat laten. Berbagai karakteristik jasa di atas, dianggap penting dalam menentukan kualitas jasa dan layanan. Zeithaml yang dikutip oleh Umar (2000), mengemukakan lima dimensi dalam menentukan kualitas jasa, yaitu sebagai berikut :

1) Reliability, yaitu kemampuan untuk memberikan pelayanan yang sesuai dengan janji yang ditawarkan.

2) Responsiveness, yaitu respon atau kesigapan karyawan dalam membantu pelanggan dan memberikan pelayanan yang cepat dan tanggap, yang meliputi : kesigapan karyawan dalam melayani pelanggan, kecepatan karyawan dalam menangani traansaksi, dan penanganan keluhan pelanggan.

3) Assurance, meliputi kemampuan karyawan atas pengetahuan terhadap produk secara tepat, kualitas keramah tamahan, perhatian dan kesopanan dalam memberi pelayanan, ketrampilan dalam memberikan informasi, 
ketrampilan dalam memberikan keamanan di dalam memanfaatkan jasa yang ditawarkan, dan kemampuan dalam menanamkan kepercayaan pelanggan terhadap perusahaan.

4) Emphaty, yaitu perhatian secara individual yang diberikan perusahaan kepada pelanggan seperti kemudahan untuk menghubungi perusahaan, kemampuan karyawan untuk berkomunikasi dengan pelanggan, dan usaha perusahaan untuk memahami keinginan dan kebutuhan pelanggannya.

5) Tangibles, meliputi penampilan fasilitas fisik seperti gedung dan ruangan front affice, tersedianya tempat parkir, kebersihan, kerapihan dan kenyamanan ruangan, kelengkapan peralatan komunikasi, dan penampilan karyawan. Aplikasi dari kualitas sebagai sifat dari penampilan produk atau kinerja merupakan bagian utama strategi perusahaan dalam rangka meraih keunggulan yang berkesinambungan, baik sebagai pemimpin pasar ataupun strategi untuk terus tumbuh. Bitner et al. (1994), melalui penelitiannya menyatakan bahwa jasa merupakan keseluruhan kesan konsumen terhadap inverioritas atau superioritas organisasi beserta jasa yang ditawarkannya. Sementara itu Cronin dan Taylor (1992) menyatakan bahwa untuk memperkirakan kualitas dari suatu perusahaan, sampai saat ini belum ada penelitian yang dinilai objektif, akan tetapi biasanya dengan mengukur kinerja dari jasa yang dikonsumsikan oleh konsumen.

\section{Kualitas produk}

Produk merupakan barang untuk jasa yang hasilnya digunakan untuk konsumen guna memenuhi kebutuhan dan memberikan kepuasan (Mraz, 1997). Demikian produk adalah segala sesuatu yang dapat ditawarkan kepada pasar untuk mendapat perhatian, dimiliki, digunakan atau dikonsumsi untuk meliputi barang secara fisik, jasa kepribadian, tempat, organisasi dan gagasan atau buah pikiran. Mraz (1997) mengatakan bahwa produk adalah segala sesuatu yang dapat ditawarkan ke pasar untuk diperhatikan, digunakan, dikonsumsi yang akan memuaskan semua kebutuhan atau keinginan.

\section{Loyalitas pelanggan}

Loyalitas pelanggan pasti ditujukan pada obyek tertentu. Obyek dimaksud berupa merk, atribut pada produk dan perusahaan atau tempat penjualan. Oleh karena istilah loyalitas bermacam-macam seperti loyalitas merk, loyalitas terhadap perusahaan dan tempat penjualan tertentu. Dengan demikian makna loyalitas secara umum dapat diartikan sebagai kecenderungan konsumen untuk membeli suatu produk. Pada merk tertentu dengan tingkat konsistensi yang tinggi (Basu, 1999) mengajukan empat macam pengukuran loyalitas merk, yaitu sebagai berikut. a.Runtutan pilihan merk (brand-choice sequence), $\mathrm{b}$. Proporsi pembelian ( proportion of 
purchase), c. Preferensi merk (brand prefence), d. Komitmen merk (brand commitment)

\section{METODE PENELITIAN}

\section{Jenis dan Rancangan Penelitian}

Penelitian yang digunakan adalah dengan pendekatan kuantitatif. Dimana penelitian kuantitatif menekankan pada pengujian teori teori melalui pengukuran variabel penelitian dengan angka dan melakukan analisis dengan prosedur statistik. Dalam penelitian ini peneliti menggunakan tiga macam variable yaitu kualitas layana sebagai variable (X1), kualitas produk sebagai (X2) dan loyalitas pelanggan sebagai variable (Y)

\section{HASIL PENELITIAN DAN PEMBAHASAN}

Pengaruh Kualitas Pelayanan
terhadap Loyalitas Pelanggan

BANYU BIRU merupakan air isi ulang yang biaru dan sangat digemari oleh masyarakat, walaupun banyak beredan air minum isi ulang dan air minum yang bermarek terkenal para pelanggan BANYU BIRU masih setia dan tidak beralih mengkonsumsi air minum pesaing. Itu dikarenakan kualitas produk dan kualitas pelayanan air minum isi ulang BANYU BIRU tersebut sudah dipercaya dibenak konsumen sebagai air minum isi ulang yang bagus dan sehat.

Berdasarkan hasil yang diperoleh dari para responden bahwa kualita. Pelayanan yang diberikan oleh air minum isi ulang BANYU BIRU yang menyatakan sangat puas terhadap kecepatan pelayanan sebanyak 30 responden (42,86\%), puas 29 responden $(41,43 \%)$ dan cukup puas 11 responden (15,71\%). Terhadap keramahan dan ketrampilan pelayanan sangat puas 29 responden $(41,43 \%)$, puas 30 responden $(42,86 \%)$ dan cukup puas 11 responden $(15,71 \%)$. Pemberian bonus dan sistem pembayaran sangat puas 25 responden $(35,71 \%)$, puas 28 responden $(40 \%)$ cukup puas 13 responden $(18,57 \%)$.

\section{Pengaruh Kualitas Produk terhadap Loyalitas Pelanggan}

Sedang responden yang menyatakan kualitas produk air minum isi ulang BANYU BIRU dengan variable produk air minum isi ulang BANYU BIRU selalu mencantumbakn label (nama, ijin Depkes) sangat setuju sebanyak 56 responden ( $80 \%$ ) setuju 12 responden $(17,14 \%)$ dan netral 2 responden. Pernyataan produk air minum isi ulang BANYU BIRU sudah sesuai standart kesehatan baik keamanan maupun kandungan gizi sangat setuju 59 responden $(84,29 \%)$ dan setuju 21 responden $(15,71 \%)$.

\section{Pengaruh Kualitas Pelayanan dan Kualitas Produk terhadap Loyalitas Pelanggan}

Loyalitas pelanggan air minum isi ulang BANYU BIRU yang dicirikan dengan pernyataan saya akan tetap membeli air minum isi ulang BANYU BIRU menyatakan sangat setuju 56 responden $(80 \%)$ setuju 13 responden $(16,57 \%)$ dan netral 1 responden. Pernyataan kualitas produk lebih tinggi 
pengaruhnya terhadap kualitas pelayanan yang diberikan oleh pegawainya sangat setuju 43 responden $(61,43 \%)$ ) setuju 25 responden ( $35,71 \%$ ) netral 2 responden. Sedang pernyataan yang akan menyampaikan kepada teman, kolega maupun keluarga, sangat setuju 56 responden (80\%) setuju 13 responden $(16,57 \%)$ dan netral 1 responden.

Berdasarkan analisis regresi pada tabel 6 diperoleh hasil, bahwa kualitas pelayanan dan kualitas produk secara bersama-sama berpengaruh positif terhadap loyalitas pelanggan. Secara statistik kualitas pelayanan tidak berpengaruh terhadap loyalitas pelanggan, namun kualitas produk signifikan terhadap loyalitas pelanggan dengan tingkat kepercayaan $99 \%$. Hasil regresi ini menunjukkan, bahwa jika kualitas produk ditingkatkan $1 \%$ maka akan diikuti dengan meningkatnya loyalitas pelanggan air minum isi ulang BANYU BIRU sebesar $0,539 \%$. Hal ini diperkuat dari data rekapitulasi responden air minum isi ulang BANYU BIRU, dari hasil skor terhadap kualitas produk lebih tinggi daripada kualitas pelayanan atau dengan kata lain konsumen yang datang masih mengesampingkan kualitas pelayanan terhadap konsumen (skor rata-rata 4) dan hanya berorientasi pada kualitas air minum isi ulang BANYU BIRU (skor rata-rata 5). Kunci untuk menghasilkan loyalitas pelanggan adalah memberikan nilai pelanggan yang tinggi. Perusahaan harus merancang proposisi nilai (valueproposition) yang unggul, sehingga mampu bersaing yang dibidikkan ke segmen pasar tertentu dan yang didukung dengan sistem pemberian nilai (valuedelivery system). Proposisi nilai terdiri dari keseluruhan kelompok manfaat yang dijanjikan akan diberikan perusahaan, sebagai contoh "keamanan pangan" tetapi pembeli juga dijanjikan rasa, kemudahan digunakan, standart kualitas mutu dan label halal.

Selain itu perusahaan diharapkan dapat menyelaraskan antara nilai merek (brand value) dengan nilai pelanggan (customer value) dengan melakukan upaya penjualan yang unik seperti alternatif pilihan Bagi perusahaan yang berfokus pada pelanggan, kepuasan pelanggan adalah sasaran sekaligus alat pemasaran. Untuk itu perusahaan air minum isi ulang BANYU BIRU dapat meningkatkan nilai pelanggan dengan memperbaiki manfaat-manfaat produk, layanan karyawan dan citranya.

\section{KESIMPULAN DAN SARAN \\ Kesimpulan}

Berdasarkan analisis dan uraian pada bab-bab sebelumnya, dalam penelitianini dapat ditarik simpulan bahwa Pelanggan air minum isi ulang BANYU BIRU berdasarkan jenis kelamin terbanyak lakilakiyaitu mencapai 54,3\%, berdasar tingkat pendidikan terbanyak dariperguruan tinggi yaitu mencapai $78,6 \%$, berdasar domisili terbanyak darikota Surabaya yaitu mencapai 51,4 diikuti kota lainnya dan terakhir kotaungaran. Berdasar jenis pekerjaan terbanyak pegawai swasta mencapai38,6\%, berdasar penghasilan perbulan 
terbanyak penghasilan
Rp.2.000.000,-.
Kualitas pelayanan dalam
penelitian ini tidak terbukti
berpengaruh terhadappeningkatan
loyalitas pelanggan. Hal ini terlihat dari
skor rata-rata 4,berarti pelanggan/
konsumen yang datang
mengesampingkan kualitaspelayanan
terhadap konsumen dan hanya
berorientasi terhadap kualitasproduk
air minum isi ulang BANYU BIRU.

Meningkatnya kualitas produk secara signifikan dapat meningkatkanloyalitas pelangan air minum isi ulang BANYU BIRU, sebagaimana terbukti dalampenelitian ini. Hal ini diketahui dari jawaban responden bahwa yang sangatmempengaruhi jadi pelanggan adalah produknya atau rasanya lebih enakdan mereka percaya bahwa air minum isi ulang BANYU BIRU tidak memakai bahanpengawet.

Secara bersama-sama kualitas pelayanan dan kualitas produk signifikandapat meningkatkan loyalitas pelangan air minum isi ulang BANYU BIRU

\section{Saran}

Berdasarkan pembahasan dan hasil analisis data yang dilakukan dalam penelitian ini dapat disarankan beberapa hal antara lain yaitu, karena kualitas pelayanan tidak terbukti berpengaruh terhadap peningkatanloyalitas pelanggan, maka kualitas pelayanan oleh karyawan air minum isi ulang BANYU BIRU dapat ditingkatkan melalui pelayanan prima, yang meliputi kecepatan,ketepatan dan komunikasi antara penjual dan pelanggan, sehinggapelanggan merasa nyaman.

Karena kualitas produk secara signifikan berpengaruh terhadap peningkatanloyalitas pelanggan, maka kualitas produk yang dihasilkan dipertahan danbila perlu ditingkatkan melalui teknologi pengolahan dan pengemasannya,bila perlu dituliskan batas masa kadaluwarsa produk.

Perlu ada penelitian lanjutan tentang kualitas produk air minum isi ulang BANYU BIRUbaik yang menyangkut rasa, keamanan baik dari bahan pengawet maupunbahan tambahan sehingga dapat diketahui kualitas produk yang sebenarnya.

\section{DAFTAR PUSTAKA}

Anwar, S. 1997. Validitas dan Rentabilitas, BPFE, Yogyakarta

Basu. S 1999. Loyalitas Pelanggan, Sebuah Kajian Konseptual. Sebagai Panduan bagi peneliti, Jurnal Ekonomi dan Bisnis Indonesia. 1999 Bo. 14. No. 3, 73-88

Basu. S, T.H. Andika, 1987, Manajemen Pemasaran Analisa Perilaku Konsumen,

Cetakan Kedua, Penerbit Liberty Yogyakarta.

Dick, AS and K. Basu, 1994 Customer Loyality - Toward and Integrated Conceptual Framework, Journal of The Academy of Marketing Scince Vol 22, No. 2 (Spring), 99 113 
Dwiloka B, Nurwantoro, Supardi, 2005, Pengawasan Mutu Hasil Ternak Perpustakaan Nasional : Katalog Dalam Terbitan (KDT).

Fornell, C. 1992. A. National Customer Satisfaction Barometer, The Swedish

Experince, Journal of Marketing. Vol 56, Januari, pp 6-21

Ghozali, Imam (2005) Analisis Multivariate Aplikasi dengan program SPSS. Semarang

Gujarati, Damodar N (2003). Basic Econometrics Fourth Edition Internasional

Editio. McGraw-Hill Singapore Kotker, P.1997, Marketing Management : Analysis, Planning, Implementation and Control,Prestice Hall, Inc

Mardalis, 1989, Metode Penelitian Suatu Pendekatan Proposal, PT. Bumi Aksara Jakarta.

M. Zein, 1995, The Important of Experience in Moulding Customer Loyality, Behavior, Letela No. 84, 1995, Malaysia.

Parasuraman, Valeri A. Zeithaml, and Leonard L Berry, A. Conceptual Model of

Serivice L. and Its Implications for Future Research, Journal of

Marketing, No. 49 (Fall), 1985, PP $41-50$

SERVQUAL = A, Multiple, Item Scala For Measuring Costumer
Perceptions of Service Quality, Journal of Retailing No. 64 (1), 1988, PP. 12- 40

Peter J.P dan OC, Jerry C. 1999. Perilaku konsumen dan strategi pemasaran.

Erlangga, Jakarta.

Saputra, Alim .2000. Pengaruh kualias produk terhadap pembelian ulang produk baju online study kasus daerah surabaya. Jurnal. Surabaya

Syafitri. 2009. Hubungan kualitas layanan terhadap loyalitas pelanggan study kasus warung apung semarang, jurnal. Semarang

Sujarweni V Wiratna (2007), Panduan mudah menggunakan SPSS.

Stephan A. Butscher, Membangun Klub Pelanggan Itu Mudah, Seri Manajemen Pemasaran No. 13. Penerbit PPM. 2006.

Tjiptono, F. 1997, Prilaku Konsumen, Andy Yogyakarta F. 1997, Strategi Pemasaran. Andy Yogyakarta

Zein, Af, L. 1998 Attitude Personality and Behavior, Engle wood Cliff. N.J Printice Hall.Inc 
